\title{
DPR Sebagai Pemediasi Antara CAONS, DTAR, Dan GCG Pada Harga Saham
}

\author{
Ainun Jariah \\ STIE Widya Gama Lumajang \\ Email : anjar040820@gmail.com
}

\begin{abstract}
The company's performance projections are the focus of investors, especially investment decisions, funding decisions, and dividend policies, plus GCG which contribute to stock price volatility. The purpose of his research to detect the influence of CAONS, DTAR, and GCG individually and simultaneously on DPR and share prices, with DPR as a mediator. The number of samples 37 industry company registered on the BEI during 5 years since 2012. Analysis of data is path analysis and sobel tests for mediation variables. The research results explain that partially DTAR and GCG have a significant effect on DPR. but the share prices all three variables have no significant impact. Simultaneously CAONS, DTAR, and GCG have a significant impact on DPR and than no significant on share price. DPR has an effect and significant on share prices. Partially and simultaneously CAONS, DTAR, and GCG have no relationship to stock prices through DPR, and DPR is only able to mediate CAONS to stock prices.
\end{abstract}

Keyword: CAONS, DTAR, GCG, DPR, and Stock Prices.

\section{Pendahuluan}

Nilai perusahaan selalu melekat dengan harga saham, harga saham mahal nilai perusahaan naik, harga saham rendah nilai perusahaan bakal jatuh. Harga saham menjadi sasaran utama manajemen keuangan perusahaan dan selalu menjadi perhatian para investor. Investor sebelum berinvestasi selalu memperhatikan penilaian atas harga saham perusahaan. Harga saham sebuah perusahaan ditetapkan berdasar pada penawaran dan permintaan saham itu sendiri. Saham merupakan kertas yang mencantumkan angka nominal, nama perseroan beserta hak dan kewajiban yang ditegaskan pada tiap pembelinya (Fahmi, 2015; 271). Menurut Sartono (2010:70) nilai yang tercipta berdasar atas permintaan penawaran pasar modal. Permintaan meningkat, harga cenderung naik. sedangkan, 
penawaran meningkat harga bergerak turun (Agus, 2010).

Harga saham akan terus naik disebabkan oleh banyaknya pembeli dan jika banyak investor melakukan penjualan atas sahamnya maka dipastikan harga cenderung menurun. Proyeksi kinerja/performa perusahaan menjadi sorotan dan acuan para investor sebelum melakukan aktivitas investasi, terutama mengenai keputusan penempatan dana, keputusan pencarian dana, kebijakan pembagian laba, $G C G$ perannya terhadap naik turunnya harga saham perusahaan. Oleh karenanya keputusan manajemen keuangan dan tata kelola perusahaan yang baik wajib diperhatikan manager keuangan perusahaan.

Keputusan investasi sangat berperan pada naik turunnya harga saham, komposisi investasi menjanjikan menarik investor menanamkan dananya pada perusahaan, selanjutnya membuat nilai saham perusahaan naik atau meningkat. Dalam hal ini keputusan investasi menggunakan rasio investment opportunity set focus pada kemampuan asset lancar dalam menghasilkan penjualan bersih, dengan menggunakan proksi CAONS. CAONS adalah ratio kesempatan investasi yang mencerminkan perbandingan antara total asset lancar terhadap penjualan bersih (Hardiningsih, 2009). Suatu skala yang digunakan untuk mengetahui kemampuan perusahaan menciptakan penjualan netto berdasar total asset lancar yang dimiliki.

Keputusan pendanaan mengatur tentang asal modal dalam membiayai investasi yang layak. Terdapat dua sumber pembiayaan perusahaan, internal dan eksternal. Laba di tahan dan penjualan saham biasa merupakan sumber dari dalam perusahaan, sedangkan hutang dan penjualan saham preferen sumber dari luar. Seorang pengambil keputusan diharapkan mampu memanajemen komposisi utang dan modal sendiri dalam mendanai operasional perusahaan. Keputusan pencarian dana akan memberikan efek pada naik turunnya harga saham. keputusan pendanaan menggunakan proksi DTAR dengan alasan ingin mendeteksi komposisi sumber total asset. Menurut Fahmi (2015: 72) rasio jumlah hutang terhadap total aset. Menjelaskan komposisi besarnya hutang pada total asset yang dimiliki perusahaan.

Kebijakan pembagian laba juga penentuan bagian dibayarkan pada pemilik dividend serta besarnya laba ditahan sebagai pembelanjaan investasi. Apabila 
lebih memilih membagi dividen akan mengurangi jumlah dana internal perusahaan. Dan jika banyak digunakan laba ditahan, selanjutnya kemampan perusahaan dalam pembentukan dana internal semakin berkurang. Karena kondisi tersebut yang menyebabkan kebijakan dividen berpengaruh pada harga saham. Kebijakan dividen menggunakan $D P R$, alasan ingin mengetahui dividen dengan laba perusahaan. DPR adalah skala dalam memperkirakan persentase bagian laba bersih untuk pemegang saham pada 1 (satu) tahun. Artinya, menyatakan besarnya alokasi keuntungan kepada pemegang saham dan distribusi keuntungan untuk mendanai operasional(Zubaidi, 2018).

Good corporate governance yaitu pedoman bagi perusahaan dalam keseimbangan kekuatan kewenangan memberikan pertanggungjawaban pada pemangku kepentingan dan shareholders. Menurut Agoes (2011:11) Good Corporate Governance adalah tata kelola mengatur peran Dewan Komisaris, dewan direksi, dan pemangku kepentingan lainnya (Agoes \& Ardana, 2011). Good corporate governance dibutuhkan guna menciptakan efisiensi pasar, keterbukaan dan konsekuen pada perundangan berlaku, intinya berperan agar pihak-pihak yang menjalankan perusahaan (pemilik saham, komite audit, kepala unit, karyawan) memahami lalu menjalankan fungsi dan tugas sesuai wewenang dan tanggung jawab. Good corporate governance akan sangat berpengaruh terhadap naik turunnya harga saham. Proksi Good corporate governance jumlah komisaris independen, dengan alasan bagaimana peran komisaris independent terhadap kebijakan perusahaan. Penelitian ini bermaksud mencari bukti pengaruh CAONS, DTAR, GCG terhadap harga saham melalui DPR. Mampukah DPR berperan sebagai pemediasi antara CAONS, DTAR, GCG dengan harga saham.

\subsection{Perumusan Masalah}

Harga saham menjadi perhatian para investor sebelum melakukan investasi, menjadi perhatian pihak manajemen dalam penentuan nilai perusahaan. Harga saham dipengaruhi factor keputusan penempatan dana, keputusan pencarian dana, kebijakan pembagian laba, dan good corporate governance. Berdasarkan hal tersebut, perumusan masalah penelitian adalah: 
a. Apakah terdapat pengaruh CAONS, DTAR, GCG secara parsial terhadap $D P R ?$

b. Apakah terdapat pengaruh CAONS, DTAR, GCG secara simultan terhadap $D P R ?$

c. Apakah terdapat pengaruh CAONS, DTAR, GCG secara parsial terhadap harga saham?

d. Apakah terdapat pengaruh CAONS, DTAR, GCG secara simultan terhadap harga saham?

e. Apakah terdapat pengaruh $D P R$ terhadap harga saham?

f. Apakah terdapat hubungan CAONS, DTAR, GCG secara parsial terhadap harga saham melalui $D P R$ ?

g. Apakah terdapat hubungan CAONS, DTAR, GCG secara simultan terhadap harga saham melalui $D P R$ ?

h. Apakah DPR mampu memediasi pengaruh CAONS, DTAR, GCG terhadap harga saham?

\subsection{Tujuan Penelitian}

Penelitian yang berkesinambungan mengenai $D P R$ dan harga saham yang dipengaruhi oleh CAONS, DTAR, good corporate governance. Maka tujuan penelitian adalah sebagai berikut:

a. Untuk mendapatkan bukti empiris CAONS, DTAR, GCG mempengaruhi DPR secara parsial signifikan.

b. Untuk mendapatkan bukti empiris $C A O N S, D T A R$, GCG mempengaruhi $D P R$ secara simultan signifikan.

c. Untuk mendapatkan bukti empiris CAONS, DTAR, GCG mempengaruhi harga saham secara parsial signifikan.

d. Untuk mendapatkan bukti empiris CAONS, DTAR, GCG mempengaruhi harga saham secara simultan signifikan.

e. Untuk mendapatkan bukti empiris $D P R$ mempengaruhi harga saham secara signifikan.

f. Untuk mendapatkan bukti empiris CAONS, DTAR, GCG mempunyai hubungan secara parsial signifikan terhadap harga saham melalui $D P R$. 
g. Untuk mendapatkan bukti empiris CAONS, DTAR, GCG mempunyai hubungan secara simultan signifikan terhadap harga saham melalui $D P R$.

h. Untuk mendapatkan bukti empiris DPR memediasi CAONS, DTAR, GCG pengaruhnya pada harga saham.

\section{Tinjauan Pustaka}

\subsection{Kajian Teori}

\section{Current Asset On Net Sales (CAONS)}

CAONS adalah ratio kesempatan investasi yang mencerminkan perbandingan antara total asset lancar terhadap penjualan bersih (Hardiningsih, 2009). Suatu skala yang digunakan untuk mengetahui kemampuan perusahaan menciptakan penjualan netto berdasar total asset lancar yang dimiliki.

\section{Debt To Total Asset Ratio (DTAR)}

Menurut Fahmi (2015: 72) rasio jumlah hutang terhadap total aset. Menjelaskan komposisi besarnya hutang pada total asset yang dimiliki perusahaan.

\section{Dividend Payout Ratio (DPR)}

DPR adalah skala dalam memperkirakan persentase bagian laba bersih untuk pemegang saham pada 1 (satu) tahun. Artinya, menyatakan besarnya alokasi keuntungan kepada pemegang saham dan distribusi keuntungan untuk mendanai operasional(Zubaidi, 2018).

\section{Good Corporate Governance (GCG)}

Menurut Agoes (2011:11) Good Corporate Governance adalah tata kelola mengatur peran Dewan Komisaris, dewan direksi, dan pemangku kepentingan lainnya (Agoes \& Ardana, 2011)

\section{Harga Saham}

Menurut Sartono (2010:70) nilai yang tercipta berdasar atas permintaan penawaran pasar modal. Permintaan meningkat, harga cenderung naik. sedangkan, penawaran meningkat harga bergerak turun (Agus, 2010).

\subsection{Kajian Empiris}

Beberapa riset oleh peneliti terdahulu, yaitu Sitorus, dkk. (2015), menguji efek $G C G$, kebijakan dividen, harga saham perusahaan manufaktur di Indonesia kurun waktu 2013 - 2015. Teknik regresi linier berganda, good corporate 
governance diukur independen komite audit berdampak positif, sedangkan yang diukur dengan kepemilikan manajerial, kepemilikan institusional, ukuran dewan direksi, ukuran dewan komisaris, komisaris independen dan kebijakan dividen tidak bepengaruh (Sitorus et al., 2015).

Penelitian Rahmawati (2014), menguji kebijakan dividen, keputusan investasi, dan harga saham perusahaan transportasi tahun 2009 - 2014. Berdasar regresi linier berganda, riset menjelaskan keputusan investasi berpengaruh pada harga saham, sedangkan kebijakan dividen tidak. Kebijakan dividen dan keputusan investasi keduanya berpengaruh (Ilmu, Dan, Politik, \& Riau, 2014).

Rohmah, dkk (2014), mengkaji peran keputusan investasi, keputusan pendanaan, kinerja keuangan pada harga saham perusahaan manufaktur di Indonesia. Dengan regresi linier berganda, riset menyatakan keputusan investasi dan keputusan pendanaan tidak signifikan. Sedang kinerja keuangan berpengaruh (Ilmu et al., 2014).

Prasetyo, dkk. (2011) mengulas pengaruh investasi dan keputusan pendanaan terhadap harga saham. Menggunakan regresi linier berganda studi menjelaskan keputusan investasi keputusan pendanaan baik secara parsial dan bersama-sama berpengaruh (Azizah, 2011).

Prastiwi dan Maslichah (2019), menganalisis pengaruh corporate governance return on equity terhadap harga saham perusahaan manufaktur tahun 2015 - 2017. Dengan regresi berganda, pengamatan membuktikan mekanisme good corporate governance dengan kepemilikan manajerial, dewan komisaris, dewan direksi, komite audit, sebagai proksinya return of equity memiliki peran terhadap harga saham (Vol, Ekonomi, Universitas, \& Malang, 2019).

Penelitian Chasanah (2008), menguji factor pembayaran dividen perusahaan di Indonesia kurun waktu 2004 - 2006. Factor-faktor tersebut meliputi DTAR, CR, ROA, IO, NSG, dan FS Dengan metode regresi linier berganda dan chow test, pengamatan menyatakan ROA dan IO memiliki pengaruh terhadap $D P R$. Berdasarkan Chow test perusahaan sebagian sahamnya dimiliki manajemen dan tidak, ROA dan FS berpengaruh terhadap DPR (Pada, Yang, \& Sahamnya, 2008). 
Penelitian Sendow, dkk. (2016), menguji lima faktor pada kebijakan dividen perusahaan manufaktur BEI selama 5 (lima) tahun sejak 2012 profitabilitas, harga saham, RETA (retained earning to total assets), likuiditas, hutang. Dengan aplikasi analisis regresi logistik, hasil pengujian menjelaskan bahwa hanya profitabilitas yang memiliki pengaruh, harga saham, RETA, likuiditas, hutang tidak mempengaruhi (Sendow, Nangoi, \& Pontoh, 2016).

Penelitian Apriliani dan Natalylova (2017), menguji delapan faktor kebijakan dividen industri di Idonesia jangka waktu 2012-2014 meliputi profitabilitas, market to book value, Firm size, likuiditas, leverage, collateral assets, net profit margin, operating cash flow per share. Dengan regresi linier berganda, pengujian menyatakan profitabilitas, ukuran perusahaan, collateral asset, dan operating cash flow per share berperan mempengaruhi, tetapi likuiditas, market to book value, dan leverage tidak memiliki pengaruh (Bisnis \& Akuntansi, 2017).

Penelitian Prasetyo dan Panggabean (2019), menguji beberapa faktor yang memiliki peran untuk mempengaruhi kebijakan dividen industri Indonesia jangka waktu 2013 - 2015. Dengan analisis data panel, pegujian menjelaskan bahwa kepemilikan institusional, leverage memiliki pengaruh negatif sedangkan ukuran perusahaan berdampak positif. Earning per share tidak mampu mempengaruhi. Selanjutnya keempat variabel ini mempunyai pengaruh simultan (Perusahaan, Terdaftar, Bursa, \& Indonesia, 2019).

Penelitian Dewi dan Sedana (2018), menganalisis empat faktor kebijakan dividen diantaranya profitabilitas, likuiditas, tingkat pertumbuhan perusahaan, ukuran perusahaan di Indonesia selama 5 tahun sejak 2011. Metode regresi linier berganda, menjelaskan profitabilitas, likuiditas, ukuran perusahaan memiliki pengaruh positif sedangkan tingkat pertumbuhan perusahaan berpengaruh negatif (Dewi \& Sedana, 2018).

Kelebihan penelitian ini pada CAONS sebagai variable kebijakan dividen dan harga saham yang belum ditemukan pada penelitian sebelumnya. Kelemahan penelitian ini pada sampel industry karena tidak focus pada satu subsector. 


\section{Metode Penelitian}

Jenis penelitian adalah survey research dengan tujuan explanatory research, serta bersifat eksploratif. Obyek penelitian meliputi CAONS, DTAR, GCG, harga saham. Dilakukan pada industri terdaftar di BEI selama 5 periode sejak 2012. Jenis data sekunder berupa laporan posisi keuangan serta laporan laba rugi dengan mengakses situs dari BEI. Sumber data internal karena data dari dalam perusahaan. Populasi, industri manufaktur yang terdaftar di BEI, rentang waktu 2012 - 2017, dengan jumlah 150. Sampel berdasar pada metode purposive sampling, kriterianya adalah:

a. Industri tercatat pada BEI minimal sejak tahun 2010 .

b. Terdapat pembagian dividen tunai selama 6 tahun sejak 2012 .

c. Satuan uang sama dalam laporan keuangan.

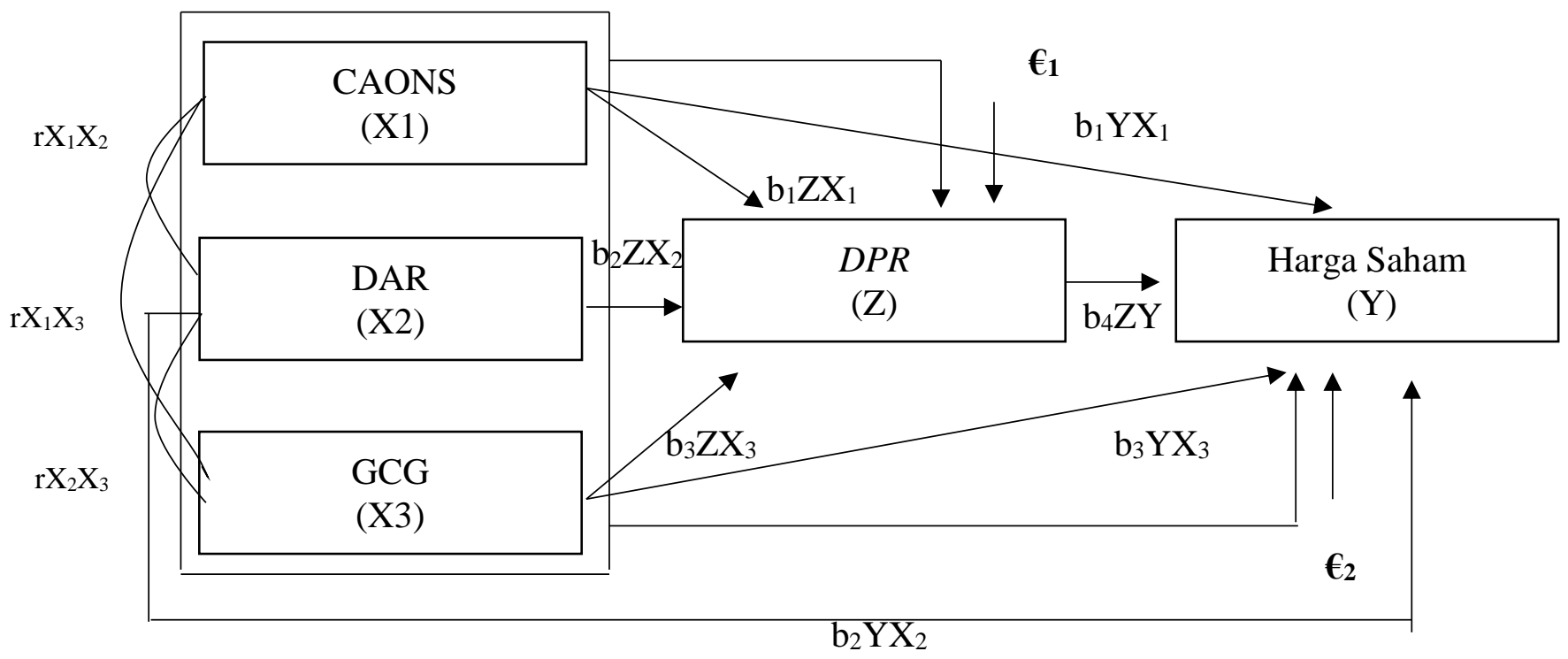

Gambar 1

Model Penelitian

\subsection{Variabel Penelitian}

Variable terikat harga saham (Y), variable moderator dividend payout ratio (DPR), variable bebas meliputi:

a. Current asset on net sales (CAONS) dikualifikasikan (X1)

b. Debt to total asset ratio (DTAR) dikualifikasikan (X2)

c. Good corporate governance (GCG) dikualifikasikan (X3) 
Relasi : Jurnal Ekonomi, Vol. 17, No. 1, Januari 2021, hlm. 202-224 


\subsection{Instrumen Penelitian}

Tabel 1 Instrumen Penelitian dan Skala Pengukuraan

\begin{tabular}{|c|l|c|c|}
\hline No & Variabel & Instrumen & Skala \\
\hline 1 & CAONS & $\frac{\text { Total Aset Lancar }}{\text { Net Sales }}$ & Rasio \\
\hline 2 & DAR & $\frac{\text { Total Hutang }}{\text { Total Assets }}$ & Rasio \\
\hline 3 & GCG & Jumlah Komisaris Independen & Rasio \\
\hline 4 & DPR & $\frac{\text { DPS }}{\text { EPS }}$ & Rasio \\
\hline 5 & $\begin{array}{l}\text { Harga } \\
\text { Saham }\end{array}$ & $\begin{array}{l}\text { Logarithm of natural dari harga penutupan } \\
\text { saham }\end{array}$ & Rasio \\
\hline
\end{tabular}

Sumber data : Fahmi (2015); Hardiningsih (2009).

\subsection{Teknik Analisis Data}

Path menggunakan aplikasi SPSS adalah teknik analisis pengujian hipotesis. Memenuhi persyaratan pengujian asumsi dasar model regresi yang telah dirancang.

\section{Pengujian Hipotesis}

\section{a. Uji Signifikansi Individual (Uji t)}

Uji $\mathrm{t}$ menunjukkan pengaruh satu variabel penjelas secara individual dalam menerangkan variasi variabel terikat dengan kriteria:

Hipotesis diterima jika $t_{\text {hitung }}<-t_{\text {tabel }}$ atau $t_{\text {hitung }}>t_{\text {tabel }}$

Hipotesis ditolak jika $-\mathrm{t}_{\text {tabel }} \leq \mathrm{t}_{\text {hitung }} \leq \mathrm{t}_{\text {tabel }}$

\section{b. Uji Signifikansi Simultan (Uji Statistik F)}

Uji statistik $\mathrm{F}$ menunjukkan variabel bebas dalam model mempunyai pengaruh secara bersama-sama terhadap variabel terikat dengan kriteria:

Hipotesis diterima jika $\mathrm{F}$ hitung $\geq \mathrm{F}$ tabel

Hipotesis ditolak jika $\mathrm{F}$ hitung $<\mathrm{F}$ tabel 


\section{Koefisien Determinan $\left(\mathbf{R}^{2}\right)$}

Menurut Suhartanto (2014:315) koefisien determinasi ada kekuatan hubungan antara $\mathrm{X}$ dan $\mathrm{Y}$ ditunjukkan dengan koefisien determinasi $\left(\mathrm{R}^{2}\right)$.

\section{Hasil Dan Pembahasan}

\section{Hasil Penelitian}

Populasi adalah industri tercatat di BEI rentang waktu 2012 - 2017. Berdasar kriteria, hanya 37 industri yang memenuhi. Berikut disajikan hasil statistic deskriptif untuk masing-masing variable selama 6 periode (enam).

Tabel 2 Statistik Deskriptif Variabel Current Asset On Net Sales

\begin{tabular}{ccccc}
\hline Tahun & & & & \\
\hline & Mean & Standar Deviasi & Min & Max \\
\hline 2012 & .5381 & .25824 & .18 & 1.18 \\
\hline 2013 & .5192 & .22203 & .19 & 1.29 \\
\hline 2014 & .5057 & .20968 & .18 & 1.29 \\
\hline 2015 & .5238 & .19237 & .18 & 1.31 \\
\hline 2016 & .5492 & .24867 & .16 & 1.43 \\
\hline 2017 & .5751 & .27352 & .19 & 1.55 \\
\hline Rata- & .5352 & .23421 & .16 & 1.55
\end{tabular}

Sumber data: Lampiran 1

Tabel 3 Statistik Deskriptif Variabel Debt To Total Asset Rasio

\begin{tabular}{rrrrr}
\hline Tahun & & & & \\
\hline & Mean & Standar Deviasi & Min & Max \\
\hline 2012 & .7624 & .58861 & .15 & 2.46 \\
\hline 2013 & .7835 & .60030 & .16 & 2.67 \\
\hline 2014 & .8524 & .70135 & .17 & 3.03 \\
\hline 2015 & .7924 & .67228 & .16 & 3.23 \\
\hline 2016 & .7914 & .70074 & .15 & 3.36 \\
\hline 2017 & .7538 & .62600 & .17 & 2.69 \\
\hline Rata- & .7893 & .64321 & .15 & 3.36
\end{tabular}

Sumber data: Lampiran 1 
Tabel 4 Statistik Deskriptif Variabel Good Corporate Governance

\begin{tabular}{rrrrr}
\hline Tahun & & & & \\
\hline 2012 & Mean & Standar Deviasi & Min & Max \\
\hline 2013 & 1.9459 & 1.12906 & .00 & 6.00 \\
\hline 2014 & 1.9189 & 1.03758 & .00 & 4.00 \\
\hline 2015 & 1.9189 & 1.10418 & .00 & 5.00 \\
\hline 2016 & 1.8378 & .95389 & .00 & 4.00 \\
\hline 2017 & 1.8919 & .92837 & .00 & 4.00 \\
\hline $\begin{array}{r}\text { Rata- } \\
\text { rata }\end{array}$ & 1.9099 & .96563 & .00 & 4.00 \\
\hline Lata & & 1.01169 & .00 & 6.00
\end{tabular}

Sumber data: Lampiran 1

Tabel 5 Statistik Deskriptif Variabel Dividend Payout Ratio

\begin{tabular}{rrrrr}
\hline Tahun & & & & Indonesia \\
\hline 2012 & 15.1322 & 89.13501 & .00 & 542.66 \\
\hline 2013 & 49.3603 & 297.63648 & .00 & 1810.88 \\
\hline 2014 & 2.8508 & 14.88224 & -.49 & 90.90 \\
\hline 2015 & 13.7670 & 82.03722 & -7.62 & 499.21 \\
\hline 2016 & 11.3122 & 65.49423 & -.19 & 398.89 \\
\hline 2017 & 12.5592 & 69.91071 & -.83 & 425.99 \\
\hline $\begin{array}{r}\text { Rata- } \\
\text { rata }\end{array}$ & 17.4969 & 136.27795 & -7.62 & 1810.88 \\
\hline
\end{tabular}

Sumber data: Lampiran 1

Tabel 6 Statistik Deskriptif Variabel Harga Saham

\begin{tabular}{|c|c|c|c|c|}
\hline \multirow[t]{2}{*}{ Tahun } & \multicolumn{4}{|c|}{ Indonesia } \\
\hline & Mean & Standar Deviasi & Min & Max \\
\hline 2012 & 8.2739 & 2.11928 & 4.09 & 13.51 \\
\hline 2013 & 8.3947 & 2.128 & 4.79 & 14 \\
\hline 2014 & 8.3354 & 1.84739 & 4.96 & 12.87 \\
\hline 2015 & 7.861 & 1.66602 & 4.8 & 11.45 \\
\hline 2016 & 7.7828 & 1.51511 & 5.55 & 11.34 \\
\hline 2017 & 7.7828 & 1.51511 & 5.55 & 11.34 \\
\hline Rata-rata & 8.0718 & 1.81564 & 4.09 & 14.00 \\
\hline
\end{tabular}

Sumber data: Lampiran 1 


\section{a. Hasil Pengujian Asumsi Klasik}

\section{Hasil Uji Normalitas}

Pengujian dengan menerapkan Probability Plot. Hasil pengujian menyatakan pola grafik normal terbukti titik-titik dekat garis diagonal, artinya model regresi tersebut berdistribusi normal.

\section{Hasil Pengujian Multikolinearitas}

Gejala multikolinieritas dilihat dari nilai VIF. Jika VIF lebih besar dari 10 mengindikasikan gejala multikolinieritas dalam model regresi. Hasil pengujian menyiratkan semua variabel model regresi menunjukkan nilai VIF cukup kecil, berada di bawah 10 dan nilai tollerance lebih besar 0,1 . Artinya semua variabel bebas tidak membuktikan adanya gejala multikolinieritas.

\section{Hasil Uji Autokorelasi}

Pengujian autokorelasi dimaksudkan untuk memeriksa adanya hubungan antara error dengan pengamatan diruntut berdasarkan waktu (data time series). Bersumber dari hasil uji, disimpulkan model regresi bebas dari autokorelasi.

\section{Hasil Heteroskedastisitas}

Uji heteroskedastisitas dibuktikan menggunakan Scatter Plot. Jika tidak ditemukan variabel yang signifikan dapat diputuskan tidak ada masalah heteroskedastisitas. Hasil pengujian mengindikasikan tidak terdapat pola jelas dari titik-titik tersebut. Artinya model regresi tidak mempunyai fenomena adanya heteroskedastisitas.

\section{b. Hasil Pengujian Hipotesis}

\section{Hipotesis 1}

Pengujian secara sendiri-sendiri tiap variabel memakai uji model substruktur kedua sebagai berikut:

\section{CAONS $\left(\mathrm{X}_{1}\right)$ terhadap DPR $(\mathrm{Z})$}

Angka t hitung sebesar -1,179 signifikansi 0,240 artinya $\mathrm{H}_{\mathrm{a}}$ ditolak dan $\mathrm{H}_{0}$ diterima, boleh dirumuskan CAONS $\left(\mathrm{X}_{1}\right)$ tidak memiliki pengaruh terhadap $D P R$ (Z). 


\section{DTAR $\left(\mathrm{X}_{2}\right)$ terhadap DPR $(\mathrm{Z})$}

Angka t hitung sebesar $-1,833$ signifikansi 0,068 , pada tingkat $\alpha(0,05), \mathrm{H}_{\mathrm{a}}$ ditolak dan $\mathrm{H}_{0}$ diterima. pada signifikansi $\alpha(0,10) \quad \mathrm{H}_{\mathrm{a}}$ diterima dan $\mathrm{H}_{0}$ ditolak, boleh dirumuskan DTAR $\left(\mathrm{X}_{2}\right)$ memiliki pengaruh terhadap $D P R(\mathrm{Z})$.

\section{GCG (X3) terhadap DPR (Z)}

Angka nilai t hitung sebesar $-1,995$ signifikan 0,047 artinya $\mathrm{H}_{\mathrm{a}}$ diterima dan $\mathrm{H}_{0}$ ditolak, boleh dirumuskan $G C G\left(\mathrm{X}_{3}\right)$ memiliki pengaruh terhadap $D P R(\mathrm{Z})$.

\section{Hipotesis 2}

Nilai $\mathrm{F}$ hitung sebesar 3,056 signifikansi 0,029 artinya $\mathrm{H}_{\mathrm{a}}$ diterima dan $\mathrm{H}_{0}$ ditolak, boleh dirumuskan CAONS, DTAR, GCG memiliki pengaruh secara simultan pada $D P R$.

\section{Hipotesis 3}

Pengujian secara sendiri-sendiri tiap variabel memakai uji model substruktur kedua sebagai berikut:

\section{CAONS $\left(\mathrm{X}_{1}\right)$ terhadap harga saham $(\mathrm{Y})$}

Angka $t$ hitung sebesar -0,061 signifikansi 0,389 artinya $\mathrm{H}_{\mathrm{a}}$ ditolak dan $\mathrm{H}_{0}$ diterima, boleh dirumuskan CAONS $\left(\mathrm{X}_{1}\right)$ tidak memiliki pengaruh terhadap harga saham (Y).

\section{DTAR $\left(\mathbf{X}_{2}\right)$ terhadap harga saham $(\mathbf{Y})$}

Angka $t$ hitung sebesar 0,513 signifikansi 0,609 artinya $\mathrm{H}_{\mathrm{a}}$ ditolak dan $\mathrm{H}_{0}$ diterima, boleh dirumuskan DTAR $\left(\mathrm{X}_{2}\right)$ tidak memiliki pengaruh terhadap harga saham (Y).

\section{$G C G\left(\mathrm{X}_{2}\right)$ terhadap harga saham $(\mathrm{Y})$}

Angka t hitung sebesar 0,878 signifikansi 0,381 artinya $\mathrm{H}_{\mathrm{a}}$ ditolak dan $\mathrm{H}_{0}$ diterima, boleh dirumuskan $G C G\left(\mathrm{X}_{3}\right)$ tidak memiliki pengaruh terhadap harga saham (Y).

\section{Hipotesis 4}

Nilai $F$ hitung sebesar 0,673 signifikansi 0,569 artinya $\mathrm{H}_{\mathrm{a}}$ ditolak dan $\mathrm{H}_{0}$ diterima, boleh dirumuskan CAONS, DTAR, GCG tidak memiliki pengaruh secara simultan pada harga saham. 


\section{Hipotesis 5}

Angka t hitung sebesar 2,252 signifikansi 0,025 artinya $\mathrm{H}_{\mathrm{a}}$ diterima dan $\mathrm{H}_{0}$ ditolak, boleh dirumuskan $D P R(\mathrm{Z})$ memiliki pengaruh pada harga saham (Y).

\section{Hipotesis 6}

Korelasi atau hubungan antara $C A O N S, D T A R, G C G$ secara individu terhadap harga saham melewati $D P R$ adalah sebagai berikut:

CAONS (X1) dan harga saham (Y) memiliki korelasi sebesar -0,064, signifikansi 0,175 artinya keduanya tidak ada hubungan yang signifikan.

DTAR (X2) dan harga saham (Y) memiliki korelasi sebesar 0,054, signifikansi 0,218 artinya keduanya tidak ada hubungan yang signifikan.

GCG (X3) dan harga saham (Y) memiliki korelasi sebesar 0,061, signifikansi 0,187 artinya keduanya tidak ada hubungan yang signifikan.

\section{Hipotesis 7}

Hubungan CAONS, DTAR, GCG secara simultan pada harga saham melewat dividend payout ratio didapat dari :

\section{CAONS, DTAR, GCG Secara Simultan Terhadap DPR.}

Diperoleh R sebesar 0,205, signifikansi 0,029 yang membuktikan bahwa ada hubungan dengan kriteria lemah dan positif serta signifikan. Nilai R square 0,042 berarti variabel CAONS, DTAR, GCG mampu menjelaskan pengaruhnya terhadap perubahan variabel $D P R$ hanya sebesar 4,2\% dan 95,8\% dijelaskan variabel lain.

\section{CAONS, DTAR, GCG Secara Simultan Terhadap Harga Saham.}

Diperoleh R sebesar 0,193, signifikansi 0,093 yang membuktikan bahwa ada hubungan dengan kriteria sedang dan positif serta signifikan. Nilai R square 0,037 artinya variabel CAONS, DTAR, GCG mampu menjelaskan pengaruhnya terhadap perubahan variabel harga saham hanya sebesar 3,7\% dan 96,3\% dijelaskan variabel lain.

\section{Hipotesis 8}

Untuk Pengujian hipotesis ini akan digunakan uji Sobel (Sobel Test)

\section{CAONS (X1) Terhadap Harga Saham (Y)}

$\mathrm{t}$ hitung berdasar uji Sobel adalah $(-3,149)<-\mathrm{t}$ table $(-1,971)$, dirumuskan $D P R$ memiliki efek mediasi antara CAONS dan harga saham. 


\section{DTAR (X2) Terhadap Harga Saham (Y)}

t hitung berdasar uji Sobel adalah $(-0,28155)$ berada diantara $-\mathrm{t}$ table $(-1,971)$ dan t table $(1,971)$, dirumuskan $D P R$ tidak memiliki efek mediasi antara $D P R$ dan harga saham.

\section{GCG (X3) Terhadap Harga Saham (Y)}

$\mathrm{t}$ hitung berdasar uji Sobel adalah $(-1,475)$ berada diantara $-\mathrm{t}$ table $(-1,971)$ dan $\mathrm{t}$ table $(1,971)$, dirumuskan $D P R$ tidak memiliki efek mediasi antara $G C G$ dan harga saham.

\subsection{Pembahasan}

\section{a. Pengaruh CAONS, DTAR, GCG Terhadap DPR Secara Parsial}

Hasil riset menyatakan DTAR dan $G C G$ memiliki pengaruh, sedangkan CAONS tidak memiliki pengaruh pada $D P R$.

\section{CAONS Terhadap DPR}

CAONS tidak mempunyai pengaruh pada $D P R$, artinya tinggi atau rendah jumlah asset lancarnya dalam menciptakan penjualan tidak berimbas pada dividen tunai pemegang saham. Hal tersebut kemungkinan perusahaan berusaha memenuhi teori signal. Selain itu menurut UU Tahun 2007 No. 40 mengenai Perseroan Terbatas, menjadi kewajiban bagi semua perseroan terutama yang memiliki saldo keuntungan positif agar supaya mendistribusikan dividen kepada para pemilik sahamnya. Alasan lainnya adalah pemegang saham ada yg tidak suka terhadap capital gain, karena mereka bependapat bahwa dividen lebih jelas daripada capital gain. Investasi pada persediaan saat ini belum selalu berdampak pada perolehan laba saat ini, bisa jadi akan berdampak pada perolehan laba di masa depan. Karena konsumen belum tentu langsung mengenal produk kita atau tertarik pada produk perusahaan. Oleh karenanya butuh waktu terkait dengan reaksi konsumen yang terkait juga dengan penjualan perusahaan.

\section{DTAR Terhadap DPR}

$D T A R$ adalah rasio keputusan pendanaan perusahaan. DTAR yakni rasio hutang menyatakan perbandingan jumlah hutang dengan jumlah keseluruhan asset. Juga menjelaskan mengenai hutang yang digunakan perusahaan untuk mendanai total asetnya. Rasio yang semakin tinggi mengindikasikan tinggi pula 
hutang yang dipergunakan mendanai investasinya pada keseluruhan asset. Tinggi hutang berarti tinggi tanggungan perusahaan berupa beban keuangan. Beban bunga merupakan leverage keuangan yang akan berpengaruh terhadap perolehan laba bersih setelah bunga dan pajak (EAT). Laba rendah dan tinggi akan berdampak pada $D P R$.

\section{GCG Terhadap DPR}

Prinsip GCG menuntun dan mewajibkan manajemen dalam mengelola perusahaan dengan baik serta memperhatikan hubungan dengan para share holder dan stake holder. Karena pentingnya prinsip ini, Indonesia dalam hal ini melalui Menko Ekuin membentuk KNKCG (Komite Nasional Kebijakan Corporate Governance), membuat pedoman mengenai GCG Indonesia. Komisaris independen bagian dari dewan komisaris tidak memihak baik direksi dan pemegang saham pengendali. Artinya dengan hadirnya komisaris independen pelaksanaan good corporate governance akan betul-betul terwujud. Akan tetapi kehadiran komisaris independen ini berdampak pada beban yang harus ditanggung perusahaan yakni honor mereka, yang mana akan mempengaruhi perolehan laba perusahaan.

\section{b. Pengaruh CAONS, DTAR, GCG Terhadap DPR Secara Simultan.}

Riset menyatakan terdapat pengaruh CAONS, DTAR, GCG secara simultan terhadap $D P R$. Artinya manajemen antara CAONS, DTAR, GCG bagi perusahaan akan berdampak baik pada dividend payout ratio. Kombinasi CAONS, DTAR, $G C G$ yang diatur dengan sangat baik oleh pelaku perusahaan dan pihak-pihak yang berkepentingan pada perusahaan akan berpengaruh terhadap DPR. Hal ini membutuhkan perencanaan dan pengalokasian yang baik dan evalusi yang rutin tiap periode, agar kondisi yang kondusif bisa terjamin dan terjaga dengan baik dan terus menerus sehingga semua pihak diuntungkan secara adil.

\section{c. Pengaruh CAONS, DTAR, GCG Terhadap Harga Saham Secara Parsial}

Riset menyatakan tidak memiliki pengaruh CAONS, DTAR, GCG secara parsial terhadap harga saham. 


\section{CAONS Terhadap Harga Saham}

Hasil riset, CAONS tidak mempunyai pengaruh terhadap harga saham, artinya tinggi dan rendahnya CAONS tidak berdampak sama sekali, disebabkan focus investor dan pasar adalah pada perolehan laba perusahaan bukan pada penjualan ataupun total asset lancarnya. Jadi bagaimana perusahaan dalam menghasilkan laba yang diperhatikan oleh investor dan pasar bukan pada komponen pendapatan dan biayanya. Hal lainnya karena dalam asset lancar bukan hanya terdiri dari persediaan saja, tetapi ada akun lain seperti misalnya kas, piutang usaha dan piutang-piutang lain jangka pendek, dan surat berharga yang mana tidak berhubungan dengan penjualan. Selain itu sampel penelitian ini tidak semuanya memiliki akun persediaan dalam total asset lancarnya, dikarenakan jenis perusahaannya berbeda. CAONS merupakan kegiatan investasi dalam asset lancar untuk menunjang penjualan, $C A O N S$ juga merupakan potensi pertumbuhan perusahaan berdasarkan pada penjualan. Karena kegiatan investasi maka CAONS akan dapat diketahui pengaruhnya pada tahun berikutnya bukan pada tahun terjadinya pengeluaran investasi. Oleh karenya CAONS tidak mempunyai pengaruh terhadap harga saham.

\section{DTAR Terhadap Harga Saham}

Riset menyatakan DTAR tidak memiliki pengaruh terhadap harga saham, tinggi ataupun rendahDTAR tidak berdampak pada harga sahamnya. Hal tersebut dikarenakan hutang perusahaan jarang sekali diperhatikan oleh investor ataupun pasar. Karena menurut sebagian pengamat kinerja keuangan perusahaan hutang bukan factor penyebab tinggi rendahnya harga saham, banyak investor menyadari hutang merupakan sumber pencarian dana perusahaan, tidak mungkin dihindari keberadaannya meskipun hutang itu merupakan pilihan.

\section{GCG Terhadap Harga Saham}

$G C G$ tidak memiliki pengaruh terhadap harga saham, tinggi rendahnya pelaksanaan $G C G$ tidak berdampak sama sekali. Hal tersebut terbukti meskipun jumlah dewan komisaris independen tiap tahun dan tiap perusahaan tetap, rata-rata berjumlah 4 sampai 6 orang, harga saham perusahaan berfluktuatif. Selain itu juga disebabkan pada kenyataannya tidak semua perusahaan tertib pada pelaksanaan 
GCG. GCG di Indonesia masih banyak yang harus dibenahi terbukti KKN (Koerupsi Kolusi Nepotisme) masih sangat merajalela, sehingga hal tersebut tidak dijadikan factor utama investor dalam membeli saham sebuah perusahaan.

\section{d. Pengaruh CAONS, DTAR, GCG Terhadap Harga Saham Secara Simultan}

Penelitian menyatakan variabel CAONS, DTAR, GCG ketiganya tidak memiliki pengaruh pada harga saham. Hal tersebut disebabkan karena secara parsial pun ketiga variable tersebut tidak berpengaruh terhadap fluktuasi harga saham, jadi jumlah asset lancer dan nilai penjualan tinggi ataupun rendah, tinggi rendahnya hutang yang dilakukan perusahaan untuk mendanai total asset, serta tinggi rendahnya tata kelola perusahaan tidak memiliki pengaruh pada harga saham.

\section{e. Pengaruh DPR Terhadap Harga Saham}

Dari 4 (empat) variable yang diteliti dalam penulisan ini hanya $D P R$ memiliki pengaruh positif pada harga saham. ini berarti saat $D P R$ tinggi harga saham juga tinggi dan ketika $D P R$ rendah, harga saham juga rendah. Sesuai teori hipotesis sinyal dividend, yang menjelaskan bahwa ketika manajemen perusahaan melakukan pembagian dividen, hal tersebut sinyal investor. Pihak manajemen ingin menunjukkan bahwa kondisi keuangan sangat sehat dan kuat karena laba yang dihasilkan sesuai harapan pemegang saham sehingga perusahaan mampu memenuhi pembayaran dividen kepada mereka. Keadaan keuangan perusahaan yang kurang sehat dan kurang kuat tidak akan sanggup membayar dividen kepada para pemegang sahamnya.

\section{f. Hubungan CAONS, DTAR, GCG Terhadap Harga Saham Melalui DPR Secara Parsial}

CAONS, DTAR, GCG tidak mempunyai hubungan terhadap harga saham melewati DPR, disebabkan bahwa atas pembahasan sebelumnya CAONS, DTAR, GCG tidak mempunyai dampak terhadap harga saham, sebab perhatian investor hanya focus pada laba perusahaan, entah laba yang tinggi ataupu laba yang stabil serta dividen yang dibagikan oleh perusahaan. Investor lebih menyukai perusahaan yang membagikan dividen. Tingginya dividen yang bayarkan meningkatkan harga saham karena banyaknya permintaan saham oleh para 
investor. Dan sebaliknya dividen yang rendah akan menyebabkan harga saham turun karena kurang diminati oleh investor.

\section{g. Hubungan CAONS, DTAR, GCG Terhadap Harga Saham Melalui DPR Secara Simultan}

CAONS, DTAR, GCG secara simultan tidak memiliki hubungan dengan harga saham melalui $D P R$. Karena terhadap harga saham CAONS, DTAR, GCG ketiganya tidak memiliki pengaruh, jadi meskipun berpengaruh terhadap $D P R$ secara simultan, maka CAONS, DTAR, GCG tidak memiliki hubungan simultan signifikan terhadap harga saham melalui DPR. Selain itu CAONS, DTAR, GCG tidak akan berdampak langsung pada dividen tetapi pada laba, jadi yang seharusnya berpengaruh adalah laba perusahaan baik laba yang meningkat ataupun menurun bisa juga laba yang rata atau stabil. Sangat tidak relevan saat kita membahas dividen kita tidak memasukkan unsur laba. Meskipun current asset on net sales, debt to total asset ratio, dan good corporate governance merupakan variable yang membentuk laba tetapi tidak serta merta jika dihubungkan dengan dividen, harus melalui laba terlebih dahulu.

\section{h. Peran DPR Dalam Memediasi CAONS, DTAR, GCG Terhadap Harga Saham}

Riset menyatakan DPR mampu memediasi CAONS, tetapi tidak memediasi DTAR dan $G C G$ secara signifikan terhadap harga saham.

Untuk CAONS, adalah keputusan investasi yang menjelaskan potensi pertumbuhan perusahaan yang didasarkan pada penjualan. Penjualan terbentuk atas dasar total asset lancer. Penjualan merupakan kegiatan menjual produk perusahaan (jasa ataupun produk berwujud) untuk mencapai keuntungan. Jadi kegiatan penjualan sangat berpengaruh terhadap perolehan laba, dan laba yang dihasilkan perusahaan juga sangat berhubungan erat dengan pembayaran dividen perusahaan.

Untuk DTAR, merupakan keputusan pendanaan dengan pengadaan utang untuk meningkatkan investasi pada total asset, menjelaskan total asset didanai oleh hutang. Dengan meningkatnya hutang yang diadakan oleh perusahaan berarti akan memunculkan biaya tetap yakni beban bunga hutang. Beban bunga 
merupakan salah satu factor yang akan berpengaruh terhadap perolehan laba. Pada saat beban bunga hutang meningkat maka laba akan menurun akan tetapi penurunan ini merupakan keuntungan bagi perusahaan karena dengan laba yang menurun maka pajak badan atau pajak pendapatan yang ditanggung perusahaan akan menurun sehingga menunjukkan bahwa kondisi keuangan perusahaan meningkat. Dengan demikian bukan hanya pihak manajemen yang menyukai kondisi ini, para dewan komisaris (perwakilan dari para pemegang saham) juga sangat berkenan dengan kondisi ini. Karena dana yang dipergunakan untuk membiayai kegiatan investasi perusahaan juga akan meningkat, sehingga para pemegang saham tidak peduli dengan dividen yang diperoleh dari perusahaan.

Untuk $G C G$, pada hasil hipotesis sebelumnya tidak memiliki pengaruh baik terhadap $D P R$ maupun harga saham. kondisi ini berakibat $D P R$ tidak mampu memediasi $G C G$ dan harga saham. Selain itu kadang investor yang diwakili oleh dewan komisaris tidak memperhatikan dividen yang manajemen perusahaan bagikan tetapi melihat perkembangan perusahaan baik penjualannya ataupun kegiatan investasi yang dilakukan perusahaan.

\section{Kesimpulan}

Bersumber pada hasil riset yang telah diulas di atas, selanjutnya diambil kesimpulan sebagai berikut, DTAR dan GCG secara parsial signifikan memiliki pengaruh terhadap DPR, CAONS tidak memiliki pengaruh. CAONS, DTAR, GCG berpengaruh secara simultan terhadap DPR dan tidak terhadap harga saham. Tidak terdapat pengaruh CAONS, DTAR, dan GCG secara parsial terhadap harga saham. DPR mempunyai pengaruh terhadap harga saham. CAONS, DTAR, dan GCG secara parsial dan simultan tidak signifikan memiliki hubungan terhadap harga saham melalui DPR. DPR mampu menjadi mediasi CAONS, tetapi tidak mampu memediasi DTAR dan GCG secara signifikan terhadap harga saham.

\section{DAFTAR PUSTAKA}

Agoes, S., \& Ardana, I. C. (2011). EtikaBisnisdanProfesiedisirevisi. Jakarta: SalembaEmpat.

Agus, S. (2010). Manajemen Keuangan Teori dan Aplikasi. Edisi Keempat. 
Yogyakarta: BPFE.

Azizah, D. F. (2011). 1 ), 2 ), 3 ), 4 ).

Bisnis, J., \& Akuntansi, D. A. N. (2017). FAKTOR-FAKTOR YANG MEMPENGARUHI MANUFAKTUR DI BURSA EFEK INDONESIA. 19(1).

Dewi, I., \& Sedana, I. (2018). FAKTOR-FAKTOR YANG MEMPENGARUHI KEBIJAKAN DIVIDEN PADA PERUSAHAAN MANUFAKTUR DI BURSA EFEK INDONESIA. E-Jurnal Manajemen Universitas Udayana, 7, 3623. https://doi.org/10.24843/EJMUNUD.2018.v07.i07.p07

Hardiningsih, P. (2009). Determinan Nilai Perusahaan. Jurnal Akuntansi Indonesia, 5(2), 231-250.

Horne, J. C. Van, \& Wachowicz, J. M. (2007). Fundamentals of Financial ManagementPrinsip-prinsip Manajemen Keuangan Buku 2 Edisi 12. Jakarta: Salemba Empat.

Ilmu, F., Dan, S., Politik, I., \& Riau, U. (2014). Pengaruh kebijakan dividen dan keputusan investasi terhadap harga saham pada perusahaan transportasi yang terdaftar dibursa efek indonesia periode 2009-2014. 1-8.

Keown, A. J., Martin, J. D., Petty, J. W., \& Scott, D. F. (2008). Manajemen Keuangan: Prinsip dan Penerapan. Edisi Kesepuluh. Jakarta: PT Indeks.

Kusuma, R. A. (2016). PENGARUH ECONOMIC VALUE ADDED ( EVA ) DAN MARKET VALUE ADDED ( MVA ) TERHADAP RETURN SAHAM ( Studi pada Perusahaan yang Terdaftar dalam Indeks LQ45 di Bursa Efek Indonesia Periode 2012-2016 ). 61(3), 65-72.

Pada, P., Yang, P., \& Sahamnya, S. (2008). FAKTOR-FAKTOR YANG MEMPENGARUHI DIVIDEND PAYOUT RATIO ( DPR ) PADA PERUSAHAAN YANG LISTED DI BURSA EFEK.

Perusahaan, P., Terdaftar, Y., Bursa, D. I., \& Indonesia, E. (2019). KEBIJAKAN DIVIDEN PADA PERUSAHAAN YANG TERDAFTAR DI BURSA EFEK INDONESIA PERIODE 2013-2015. (September). https://doi.org/10.35313/irwns.v10i1.1497

Sendow, G. J., Nangoi, G. B., \& Pontoh, W. (2016). Faktor - Faktor Yang Mempengaruhi Kebijakan Dividen Pada Perusahaan Manufaktur Yang 
Terdaftar Di Bursa Efek Indonesia Periode Tahun 2012-2016. 317-329.

Sitanggang, B. P. (2014). PENGARUH PRICE EARNING RATIO, RETURN ON INVESTMENT, DAN DIVIDEN PER SHARE TERHADAP RETURN SAHAM PADA PERUSAHAAN MANUFAKTUR DI BURSA EFEK INDONESIA. UNIMED.

Sitorus, R. K., Ruwanti, S., Husna, A., Ekonomi, F., Maritim, U., Ali, R., \& Riau, K. (2015). PENGARUH GOOD CORPORATE GOVERNANCE DAN KEBIJAKAN DIVIDEN TERHADAP HARGA SAHAM ( STUDI EMPIRIS PADA PERUSAHAAN MANUFAKTUR YANG TERDAFTAR DI BURSA EFEK INDONESIA PERIODE 2013-. 1-32.

Sudarmakiyanto, E., Prasetya, H., \& Anoraga, P. (2012). ( Studi Empiris pada Perusahaan Sektor Property, Real Estate, and Building Construction yang Terdaftar di Bursa Efek Indonesia Periode 2008-2012 ).

Tandelilin, E. (2010). Portofolio dan Investasi: Teori dan aplikasi. Kanisius.

Vol, E., Ekonomi, F., Universitas, B., \& Malang, I. (2019). E-JRA Vol. 08 No. 06 Agustus 2019 Fakultas Ekonomi dan Bisnis Universitas Islam Malang. 08(06). 